in vivo $31: 1047-1050(2017)$

doi:10.21873/invivo.11168

Review

\title{
Ghrelin and Obesity: Identifying Gaps and Dispelling Myths. A Reappraisal
}

\author{
MARINOS C. MAKRIS ${ }^{1,2}$, ANDREAS ALEXANDROU ${ }^{3}$, EFSTATHIOS G. PAPATSOUTSOS ${ }^{4}$, \\ GEORGE MALIETZIS $^{5}$, DIAMANTIS I. TSILIMIGRAS ${ }^{3}$, ALFREDO D. GUERRON ${ }^{6}$ and DEMETRIOS MORIS ${ }^{6}$ \\ ${ }^{1}$ First Surgical Department, G. Gennimatas General Hospital of Athens, Athens, Greece; \\ ${ }^{2}$ Alpha Institute of Biomedical Sciences, Marousi, Athens, Greece; \\ ${ }^{3}$ First Department of Surgery, Laikon General Hospital, Athens, Greece; \\ ${ }^{4}$ Department of General Surgery, St Marien Hospital, Buer, Germany; \\ ${ }^{5}$ Department of Colorectal Surgery, St. Mark's Hospital, London, U.K.; \\ ${ }^{6}$ Division of Metabolic and Weight Loss Surgery, Department of Surgery, Duke University, Durham, NC, U.S.A.
}

\begin{abstract}
The etiology of obesity is complex. Environmental and genetic causes have been implicated in the development of this disease. Ghrelin is a hormone known to stimulate appetite. There are numerous possible actions through which ghrelin exerts its effect in the body: a) Overproduction of ghrelin, b) reduced ghrelin following meals, and c) increased receptor sensitivity to ghrelin action. Sleeve gastrectomy, a bariatric procedure, leads to reduction of ghrelin levels and subsequently to weight loss. However, there are many limitations to measurement of the fasting plasma level of the active form of ghrelin. The establishment of the exact correlation between ghrelin, appetite and obesity could be vital for the fight against obesity.
\end{abstract}

Obesity is a major public health problem as more than $10 \%$ of the global population is obese (1). The number of patients affected by this modern epidemic and the associated comorbidities, such as diabetes mellitus, cardiovascular diseases and cancer, are constantly rising, along with the associated health costs, making the management of obesity one of paramount importance $(2,3)$.

This article is freely accessible online.

Correspondence to: Demetrios Moris, MD, Ph.D., MACS, Department of Surgery, Duke University, Durham, NC, U.S.A. E-mail: dimmoris@yahoo.com

Key Words: Ghrelin, obesity, appetite, hormone levels, diet, bariatric surgery, review.
There are mainly two ways to manage obesity: the conservative one (e.g. diet, exercise and lifestyle changes) and the surgical approach through various weight-loss surgical procedures, widely known as bariatric surgery.

Surgery not only leads to malabsorption (calories are not taken up by the intestine), mechanical restriction (less room for food), but also to hormonal changes that lead to less hunger or earlier satiety postprandially $(3,4)$.

During the past couple of decades the identification of circulating factors that contribute to the induction of hunger (orexigenic) or satiety (anorexigenic) has diversified the cause of food restriction after bariatric surgery apart from being solely a mechanical phenomenon to a more complex effect of both anatomical and humoral modifications induced by the different operative strategies.

Ghrelin is a well-known orexigenic hormone that stimulates food intake in a dose-dependent manner (5-8). Ghrelin increases appetite both by initiating homeostatic feeding driven by metabolic need and by non-homeostatic feeding, acting centrally and affecting the modulation of reward, memory and motivated feeding behavior (9).

In this review, we planned to highlight the available data regarding the appetite-generating effect of ghrelin. We searched the literature in order to find determinants with a proven direct positive feedback in appetite.

\section{Structure of Ghrelin}

Ghrelin was discovered in 1999. It exerts its orexigenic action is through its relation to specific hypothalamic receptors. It is an acylated peptide, composed of 28 amino acids which is an endogenous ligand to the secretagogue receptors of growth 
Table I. Main literature findings and uncertainties regarding the role of ghrelin in obesity.

\begin{tabular}{ll}
\hline Proven role of ghrelin in obesity & Areas of uncertainty \\
\hline $\begin{array}{l}\text { Ghrelin promotes obesity via its overproduction, decreased suppression } \\
\text { following meals/increased receptor sensitivity to ghrelin action. }\end{array}$ & Very small number of studies and randomized controlled trials \\
$\begin{array}{l}\text { Diets and dietary-induced weight loss have been linked to ghrelin increase } \\
\text { Bariatric surgery succeeds in reducing body weight by changing } \\
\text { the metabolic profile, including the level of ghrelin }\end{array}$ & $\begin{array}{l}\text { Majority of published studies only measured total ghrelin } \\
\text { Lack of standardization in measurement of ghrelin in terms } \\
\text { of timing and method of sample, follow-up period, } \\
\text { storage, and radioimmunoassays. } \\
\text { Active form of ghrelin is reportedly unstable at room temperature, } \\
\text { making the exact measurement challenging }\end{array}$ \\
$\begin{array}{l}\text { Sleeve gastrectomy achieves weight loss in a different manner compared } \\
\text { to the gastric bypass procedure }\end{array}$ & \begin{tabular}{l} 
mathe \\
\hline
\end{tabular}
\end{tabular}

hormone (5). It is secreted primarily by endocrine cells of the oxyntic glands of the gastric fundus and to a lesser extent by the body of the stomach, the mucosa of the duodenum and jejunum, the lungs, the urogenital organs, and the pituitary gland. The enzyme ghrelin $\mathrm{O}$-acyltransferase performs octanoylation of the inactive form in order to produce the active one, attaching an acyl side chain to the serine residue at position 3. This chain is critical both for the orexigenic and the gastric-emptying actions of ghrelin (9). Its discovery has shed new light on many physiological functions. Among the several actions of this peptide in the human body, ranging from its involvement in the regulation of the immune and cardiovascular systems to the up-regulation of insulin-like growth factor, it has a dominant role in the gastrointestinal system, with involvement in gastric emptying and intestinal motility (10-14).

\section{Ghrelin and Appetite}

The exact role of ghrelin in the pathophysiology of obesity is still under investigation; a well-defined explanation and understanding of the initiation of appetite by the increase in the level of ghrelin could be revolutionary and create new ways for the management or even the 'treatment' of obesity. In a number of studies it has been reported that postprandial suppression of ghrelin is lower in obese groups compared to controls with normal body mass index (BMI); this is a reasonable and novel approach to the higher consumption of food by the obese as obese individuals still have the sense of hunger even after the consumption of a meal. The same finding has also been documented in obese children, supporting the 'disease pattern' of obesity which has underlying mechanisms and causes like other common disorders. Based on this scenario, the problem becomes the overproduction of ghrelin regardless of the consumption of food rather than insensitivity or oversensitivity to ghrelin (4, 15-17). The reasons for this could be many, ranging from a dysfunction in the gene for ghrelin to the production of antibodies to the receptors of peptides which antagonize the effects of ghrelin, leading to disturbances in the production and actions of ghrelin. Although studies at the molecular level do not exist, the design of studies comparing the active ghrelin level along with the appetite scored with the visual analogue scale, between matched obese and lean subjects could give many answers.

\section{Ghrelin and Diets}

As mentioned before, many studies have reported that the mean serum ghrelin level is generally lower in obese patients compared to lean individuals $(4,18,19)$. The level of ghrelin increases during dieting and this could explain why it is very difficult to achieve long-term results from dieting. Diets and dietary-induced weight loss have been linked with an increase of ghrelin level in the blood, which could potentially explain the high failure rates of diets $(18,20,21)$.

\section{Ghrelin and Bariatric Surgery}

Researchers have recently tried to explain the impressive results of bariatric surgery in terms of weight loss by evaluating the changes in ghrelin concentration following roux-en-y gastric bypass (RYGB) and especially sleeve gastrectomy (SG). In the latter procedure, the gastric fundus, where most ghrelin is produced, is totally removed. A recent meta-analysis showed that the ghrelin level does fall significantly following SG (16). In patients who undergo RYGB, the results of various studies are contradictory (21-24).

Both these techniques lead to exceptionally good results in weight loss. Based on the fact that anatomically SG is purely restrictive compared to RYGB, which additionally creates malabsorption by the rapid shunt of undigested food to the distal small intestine, the role of ghrelin is now being investigated more than ever. Perhaps the additional mechanism of reduced appetite post $\mathrm{SG}$, due to the significant lowering of the ghrelin level, can 'counterbalance' the lack of the effect of malabsorption which occurs only with RYGB not with SG. However, 


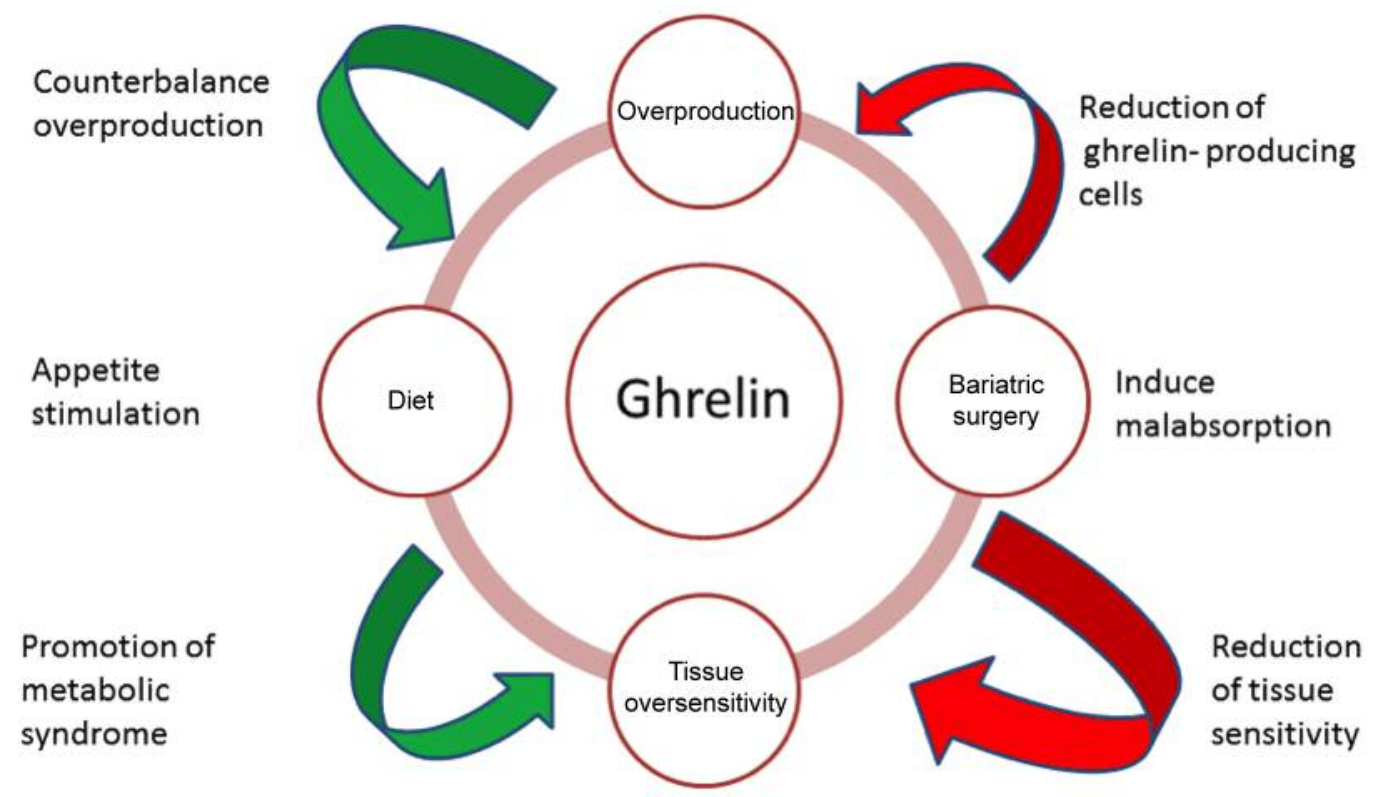

Figure 1. The role of ghrelin in obesity.

studies which have tried to evaluate the appetite of patients following bariatric surgery with measures such as the visual analogue scale score, standard tools for measuring subjective appetite sensations and the motivation to eat are extremely rare. In the randomized control trial of Karamanakos et al., 16 patients with a mean BMI of 45.1 $\mathrm{kg} / \mathrm{m}^{2}$ underwent SG and were compared with 16 matched patients with a mean BMI of $46.6 \mathrm{~kg} / \mathrm{m}^{2}$ who underwent RYGB (25). A significant drop in the BMI [postoperative BMI of $28.9 \mathrm{~kg} / \mathrm{m}^{2}(p<0.001)$ and $31.5 \mathrm{~kg} / \mathrm{m}^{2}(p<0.001)$, respectively, in the two groups] was accompanied by a significant decrease of the fasting plasma ghrelin level in the SG- but not in the RYGB-treated group, where an increase in the fasting plasma ghrelin level was noted. Interestingly, the appetite in the SG group remained below $50 \%$ of the initial preoperative score; on the contrary, the appetite in the RYGB-treated group had partially recovered by the end of the 12-month follow-up.

\section{Ghrelin and Anorexia}

Due to the proven relationship of ghrelin with appetite, researchers are also investigating the potential connection of ghrelin to anorexia. Insight into the modification of the endogenous ghrelin system seems to be promising not only for the control of obesity, but also for the management of clinically significant anorexia and pathological weight reduction. Accumulating evidence has shown that in patients with anorexia nervosa, there is a paradoxical increase in plasma ghrelin level even when compared with matched controls or obese patients (26), suggesting that there might be an insensitivity to ghrelin (27). Moreover, in vitro studies have documented that intra-peritoneal or systemic administration of ghrelin has the potential to improve the appetite and the nutritional status, and at the same time reduce the metabolic rate in patients with end-stage cancer (5).

Figure 1 summarizes the role of ghrelin in the development of obesity.

\section{Limitations of Studies Investigating Ghrelin}

There are several limitations in investigating ghrelin. First of all, there is a very small number of studies and RCTs. Moreover, there are two forms of circulating ghrelin, inactive ghrelin $(90 \%)$, and active acylated ghrelin $(10 \%)(15,16)$. However, in none of the published studies did the authors measure the active form, total ghrelin was usually measured (16). Moreover, the active form of ghrelin has been reported to be unstable at room temperature, making exact measurement even more challenging $(16,17)$. Finally, the lack of standardization in measurement of ghrelin levels in terms of timing of sample collection, collection method, follow-up period, storage of samples, and radioimmunoassays used could be an issue in the precision and reproducibility of the results $(16,17)$. Table I summarizes the advantages and obstacles in using ghrelin as therapeutic target in obesity. 


\section{Conclusion}

Increased appetite is a driving force for weight gain. A large body of literature documents that alterations of the orexigenic hormone ghrelin play an important role in appetite fluctuation following meals, and in the preservation of the achieved weight reduction following bariatric surgery. Further studies are needed to establish the true correlation between ghrelin and obesity, which is of vital importance in the fight against obesity.

\section{References}

1 Gill RS, Switzer N, Driedger M, Shi X, Vizhul A, Sharma AM, Birch DW and Karmali S: Laparoscopic sleeve gastrectomy with staple line buttress reinforcement in 116 consecutive morbidly obese patients. Obes Surg 22(4): 560-564, 2012.

2 Must A, Spadano J, Coakley EH, Field AE, Colditz G and Dietz WH: The disease burden associated with overweight and obesity. JAMA 282(16): 1523-1529, 1999.

3 National Task Force on the Prevention and Treatment of Obesity: Overweight, obesity, and health risk. Arch Intern Med 160(7): 898-904, 2000.

4 Dimitriadis E, Daskalakis M, Kampa M, Peppe A, Papadakis JA and Melissas J: Alterations in gut hormones after laparoscopic sleeve gastrectomy: a prospective clinical and laboratory investigational study. Ann Surg 257(4): 647-654, 2013.

5 Cheung CK and Wu JC: Role of ghrelin in the pathophysiology of gastrointestinal disease. Gut Liver 7(5): 505-512, 2013.

6 Arvat E, Di Vito L, Broglio F, Papotti M, Muccioli G, Dieguez C, Casanueva FF, Deghenghi R, Camanni F and Ghigo E: Preliminary evidence that Ghrelin, the natural GH secretagogue (GHS)-receptor ligand, strongly stimulates GH secretion in humans. J Endocrinol Invest 23(8): 493-495, 2000

7 Tschop M, Smiley DL and Heiman ML: Ghrelin induces adiposity in rodents. Nature 407(6806): 908-913, 2000.

8 Nakazato M, Murakami N, Date Y, Kojima M, Matsuo H, Kangawa $\mathrm{K}$ and Matsukura S: A role for ghrelin in the central regulation of feeding. Nature 409(6817): 194-198, 2001.

9 Monteleone $\mathrm{P}$ and Maj M: Dysfunctions of leptin, ghrelin, BDNF and endocannabinoids in eating disorders: beyond the homeostatic control of food intake. Psychoneuroendocrinology 38(3): 312-330, 2013.

10 Melissas J, Daskalakis M, Koukouraki S, Askoxylakis I, Metaxari M, Dimitriadis E, Stathaki $M$ and Papadakis JA: Sleeve gastrectomy-a "food limiting" operation. Obes Surg 18(10): 1251-1256, 2008.

11 Melissas J, Koukouraki S, Askoxylakis J, Stathaki M, Daskalakis M, Perisinakis K and Karkavitsas N: Sleeve gastrectomy: a restrictive procedure? Obes Surg 17(1): 57-62, 2007.

12 Braghetto I, Davanzo C, Korn O, Csendes A, Valladares H, Herrera E, Gonzalez P and Papapietro K: Scintigraphic evaluation of gastric emptying in obese patients submitted to sleeve gastrectomy compared to normal subjects. Obes Surg 19(11): 1515-1521, 2009.

13 Shah S, Shah P, Todkar J, Gagner M, Sonar S and Solav S: Prospective controlled study of effect of laparoscopic sleeve gastrectomy on small bowel transit time and gastric emptying half-time in morbidly obese patients with type 2 diabetes mellitus. Surg Obes Relat Dis 6(2): 152-157, 2010.
14 Melissas J, Leventi A, Klinaki I, Perisinakis K, Koukouraki S, de Bree $\mathrm{E}$ and Karkavitsas N: Alterations of global gastrointestinal motility after sleeve gastrectomy: a prospective study. Ann Surg 258(6): 976-982, 2013.

15 Camilleri M, Papathanasopoulos A and Odunsi ST: Actions and therapeutic pathways of ghrelin for gastrointestinal disorders. Nat Rev Gastroenterol Hepatol 6(6): 343-352, 2009.

16 Anderson B, Switzer NJ, Almamar A, Shi X, Birch DW and Karmali S: The impact of laparoscopic sleeve gastrectomy on plasma ghrelin levels: a systematic review. Obes Surg 23(9): 1476-1480, 2013.

17 Groschl M, Uhr M and Kraus T: Evaluation of the comparability of commercial ghrelin assays. Clin Chem 50(2): 457-458, 2004.

18 Abdemur A, Slone J, Berho M, Gianos M, Szomstein S and Rosenthal RJ: Morphology, localization, and patterns of ghrelinproducing cells in stomachs of a morbidly obese population. Surg Laparosc Endosc Percutan Tech 24(2): 122-126, 2014.

19 Vincent RP and le Roux CW: Changes in gut hormones after bariatric surgery. Clin Endocrinol (Oxf) 69(2): 173-179, 2008.

20 Cummings DE, Weigle DS, Frayo RS, Breen PA, Ma MK, Dellinger EP and Purnell JQ: Plasma ghrelin levels after dietinduced weight loss or gastric bypass surgery. N Engl J Med 346(21): 1623-1630, 2002.

21 Geloneze B, Tambascia MA, Pilla VF, Geloneze SR, Repetto EM and Pareja JC: Ghrelin: a gut-brain hormone: effect of gastric bypass surgery. Obes Surg 13(1): 17-22, 2003.

22 Holdstock C, Engstrom BE, Ohrvall M, Lind L, Sundbom M and Karlsson FA: Ghrelin and adipose tissue regulatory peptides: effect of gastric bypass surgery in obese humans. J Clin Endocrinol Metab 88(7): 3177-3183, 2003.

23 Vendrell J, Broch M, Vilarrasa N, Molina A, Gomez JM, Gutierrez C, Simon I, Soler J and Richart C: Resistin, adiponectin, ghrelin, leptin, and proinflammatory cytokines: relationships in obesity. Obes Res 12(6): 962-971, 2004.

24 Liou JM, Lin JT, Lee WJ, Wang HP, Lee YC, Chiu HM and Wu MS: The serial changes of ghrelin and leptin levels and their relations to weight loss after laparoscopic minigastric bypass surgery. Obes Surg 18(1): 84-89, 2008.

25 Karamanakos SN, Vagenas K, Kalfarentzos F and Alexandrides TK: Weight loss, appetite suppression, and changes in fasting and postprandial ghrelin and peptide-YY levels after Roux-en$\mathrm{Y}$ gastric bypass and sleeve gastrectomy: a prospective, double blind study. Ann Surg 247(3): 401-407, 2008.

26 Korek E, Krauss H, Gibas-Dorna M, Kupsz J, Piatek M and Piatek J: Fasting and postprandial levels of ghrelin, leptin and insulin in lean, obese and anorexic subjects. Prz Gastroenterol 8(6): 383-389, 2013.

27 Mequinion M, Langlet F, Zgheib S, Dickson S, Dehouck B, Chauveau $\mathrm{C}$ and Viltart O: Ghrelin: central and peripheral implications in anorexia nervosa. Front Endocrinol (Lausanne) 4: 15,2013 